\title{
Effects of recurrent sand deposition on rocky intertidal organisms: importance of substrate heterogeneity in a fluctuating environment
}

\author{
Mark M. Littler ${ }^{1}$, David R. Martz ${ }^{2}$ and Diane S. Littler ${ }^{1}$ \\ ${ }^{1}$ Department of Botany, National Museum of Natural History, Smithsonian Institution, Washington, D.C. 20560, USA \\ ${ }^{2}$ Rockwell International Space Systems 6P VAFB OFC, P.O. Box 1945, Vandenberg AFB, California 93437, USA
}

\begin{abstract}
This research represents a 3-yr (September 1975-June 1978) examination of a southern California rocky intertidal system influenced by variable sand deposition ranging from almost zero to total seasonal inundation over different portions of the study area. An apparent subclimax association of opportunistic macrophytes (Chaetomorpha linum, Cladophora columbiana, Ulva lobata, Enteromorpha intestinalis) and highly-reproductive macroinvertebrates (Tetraclita rubescens, Chthamalus fissus/dalli, Phragmatopoma californica) dominate by rapidly repopulating those lowlying microhabitats routinely buried by sand. Refuge habitats on slightly elevated rock pinnacles (sand free) were dominated by long-lived molluscs such as Mytilus californianus, Haliotis cracherodii and Lottia gigantea. The lower limits of these biotically-competent taxa (sensu Vermeij, 1978) appear to be determined by the physical smothering action of sand, rather than by the kinds of biological factors documented for other rocky intertidal habitats. The stress-tolerant Anthopleura elegantissima dominates the upper intertidal macroinvertebrate cover because of reproductive, behavioral and physiological adaptations to the stresses of aerial exposure and sand burial. The dominant plant in lower intertidal pools is the biotically-competent Phyllospadix scouleri that tolerates sand because of its large size and its rhizomatous root system which traps and binds sediments. The most numerous of the mobile macroinvertebrates, Tegula funebralis, is able to migrate away from the winter sand inundation to refuge habitats. The research reported here suggests that, with few exceptions, sand-stressed habitats primarily serve as important refuges for 2 functional groups of species: stress-tolerant strategists and opportunistic strategists.
\end{abstract}

\section{INTRODUCTION}

Much attention has been devoted, both historically and recently, to the influence of the physical environment upon rocky intertidal seascapes. Local variations in climate, partially generated by tide and wave fluctuations, reported to affect biotic patterns include salinity (Dawes et al., 1978), insolation (Dayton, 1975; Littler and Arnold, 1980), temperature (Mathieson and Burns, 1971), desiccation (Dayton, 1971; Schonbeck and Norton, 1978) and wave shock (Lewis, 1964, 1968; Jones and Demetropoulos, 1968; Seapy and Littler, 1978). The limitations imposed by these factors can also indirectly affect intertidal distributions through impact on species involved in higher-order competitive and predator/prey interactions (Connell, 1961; Dayton, 1971, 1975; Menge, 1972; Vadas, 1977). Con- nell (1972) emphasized the general trend for upper limits of intertidal organisms to be determined by stressful physical parameters, while biological factors such as predation and competition often control the lower zonal levels.

Since, conceptually, strictly rocky intertidal habitats should be independent of the influences of sand abrasion and deposition, the impact of this factor rarely has been examined. However, most rocky shores include considerable sand intermixed with the biota attached to rock substrates, and fluctuations in the degree of sand coverage are common (Littler, 1980a). We have observed (Littler and Littler, 1980a) that rocky intertidal systems which superficially appear to be removed from the influence of sand are often seasonally affected. Conceivably, sand movements could directly impact intertidal organisms by smothering or scouring, 
as well as contribute to indirect effects if the species affected are involved in biological interactions that have important direct influences.

Previous studies of sand effects in rocky intertidal habitats have been limited primarily to taxonomic lists from sand-impacted areas (Lewis, 1964; Mathieson and Fralick, 1972) or, in a few cases (Markham, 1973; Daly and Mathieson, 1977), to examinations of life histories and structural adaptations of single species or groups of related taxa. Quantitative treatments covering both faunistic and floristic elements are few (Taylor and Littler, 1982), including seasonal data detailed enough for characterization of sand-influenced intertidal community dynamics. Sediments have been implicated to be generally detrimental in a number of subtidal investigations (e.g. Kitching et al., 1934; Kitching, 1941; Lilly et al., 1953; Ebling et al., 1960; Foster, 1975; Neushul et al., 1976; Norton et al., 1977). During a laboratory investigation of sand effects on Macrocystis gametophytes, Devinny and Volse (1978) postulated the following 3 mechanisms of sediment damage to attached algae: (1) smothering due to reduced light, nutrients or dissolved gases; (2) physical injury due to scouring; and (3) detrimental chemical changes of the surrounding interstitial micro-environment. Conversely, Foster (1975) suggested that occasional burial by shifting sand may be an important factor in maintaining subtidal kelp-bed diversity by permitting the co-existence of opportunistic species on patches of cleared substrates. One of the purposes of the present investigation was to examine this concept (cf., Levin and Paine, 1974) from a microhabitat perspective.

This research represents a $\sim 3-y r$ examination of a rocky-intertidal system influenced by variable sand deposition ranging from almost zero to total seasonal inundation over different portions of the study area. The distributional patterns and abundances of biota in this system represent apparent responses to the degree of sand inundation, and considerable circumstantial evidence is presented to suggest its effects on community structure in conjunction with gradients of spatial heterogeneity.

\section{STUDY AREA}

The study site is on San Nicolas Island (Fig. 1), one of the Southern California Islands. The shoreline of the island is composed of sandy beaches interrupted by sandstone (quartz and feldspar) platforms that extend $40 \mathrm{~m}$ or more seaward. One such platform near Dutch Harbor (33 $12^{\prime} 55^{\prime \prime} \mathrm{N}, 119^{\circ} 28^{\prime} 16^{\prime \prime} \mathrm{W}$, Fig. 1) was studied quarterly from September 1975 to June 1978. This $70 \mathrm{~m}$ long platform averages $1.0^{\circ}$ in siope and is interrupted at its seaward margin by a series of ridges

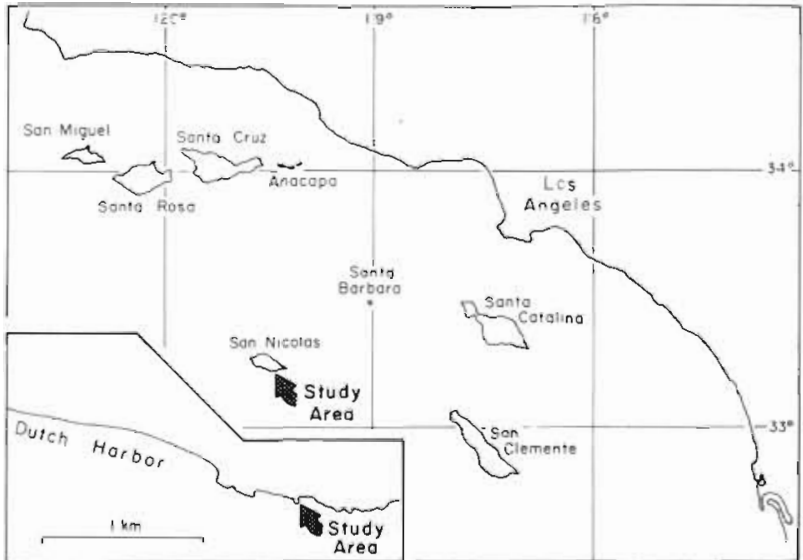

Fig. 1. Location of the platform studied on San Nicolas Island

with deep surge channels, exposed to the full force of waves. Small-scale topographic relief was prevalent at certain quadrat locations, such as W-30 (west line, meter 30), W-42, E-0 and E-39, which contained small pinnacles that were abruptly elevated relative to the other samples.

The annual pattern of sand influx along the Pacific Northwest (Hedgpeth, 1957; Markham, 1973; Shephard 1973) shows increased deposition in rocky intertidal habitats throughout the summer months. Presumably, reduced surf and the consequent shoreward movement of sand accounts for the observed sand accumulations. Interestingly, the dynamics of sediment movement at Dutch Harbor represent a reverse pattern (Fig. 2; Taylor and Littler, 1982), with the maximum inundation coinciding with high winter surf that redistributes the sand from the steeply-profiled upper shoreline downward onto the platform. This process is augmented by an eastward longshore transport of sand from the berm of the adjacent sandy beach. Waves consistently break over the seaward raised portions and surge channels of the platform which, consequently, remain unburied. As a result of this turbulence, the longshore transport of sand is interrupted and material is deposited only upon the shoreward (upper region) of the platform. Because the longshore sand flux is from the beach to the west, a distinct 'leeward' habitat is produced on the eastern margin of the platform that remains free of sand deposition.

\section{METHODS AND MATERIALS}

During each quarterly assessment (from September 1975-June 1978), photographs of $30 \times 50 \mathrm{~cm}$ quadrats $\left(0.15 \mathrm{~m}^{2}\right)$ were taken along 2 parallel transect lines (60 $\mathrm{m}$ in length) during low tide at right angles to the substrate with $35 \mathrm{~mm}$ cameras equipped with elec- 
tronic flash units (Littler, 1971); also, detailed field notes were tape-recorded of species' locations, composition and abundance for later analysis in the laboratory.

A minimum of 2 photographic transparencies were taken for each sample quadrat, one using color film (Kodachrome 64) and the other Ektachrome infrared film. Infrared photographs increased the accuracy in measuring the abundances of certain macrophytes, particularly the blue-green algae, and revealed the presence of unhealthy or bleached thalli. In cases where sampling included multilayered canopies, additional photographs were taken to measure stratification after the upper layers were carefully moved aside.

Species composition and cover were determined in the laboratory for each quadrat from analyses of the photographs and field notes (Littler, 1980a); cover assessments of macroinvertebrate and macrophyte standing stocks were made by the point-intercept method. Species observed in quadrats but not encountered by point-intercepts were assigned a cover value of $0.1 \%$. The mean cover was determined for the major species in each $0.3-\mathrm{m}$ tidal interval and used to plot distribution and abundance patterns over all intervals sampled. The data were summed and averaged to yield mean cover values for each population.

\section{RESULTS}

\section{Sedimentation patterns}

Accumulation of sand along the transects was most pronounced from December through February and displayed a recurrent annual cycle (Fig. 2). Mean cover of sand ranged from zero to $6.3 \%$ between June and

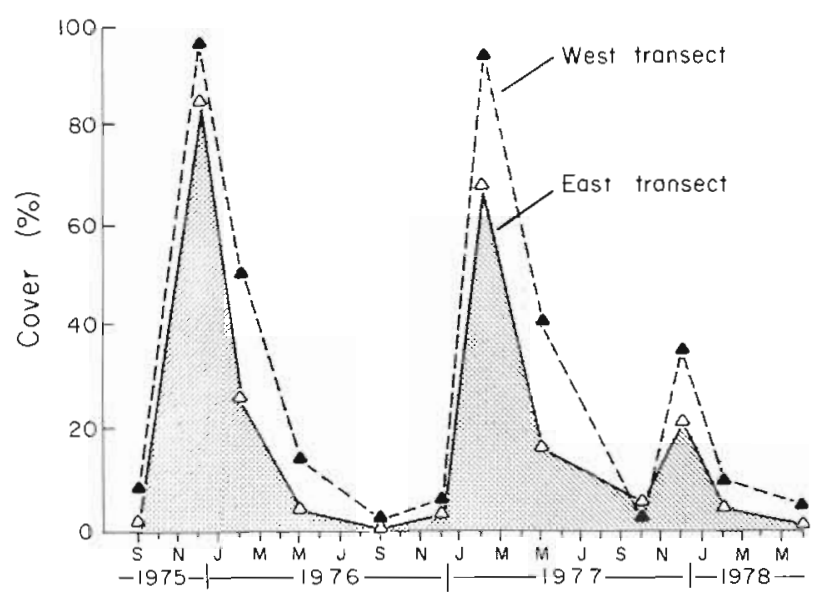

Fig. 2. Patterns of sand cover throughout the entire intertidal zone (MLLW to $+5.0 \mathrm{~m}$ )
October, with most quadrats becoming entirely uncovered during this time, while average winter cover was frequently in excess of $35.0 \%$ (range $4.4 \%$ to $96.2 \%$ and up to $10 \mathrm{~cm}$ deep). The characteristic pattern of inundation from the upper portions of the west line to the lower levels of the east transect produced a recognizable gradient of differential sand stress (i.e. smothering and bleaching) among the samples (Fig. 3). Over comparable tidal ranges, the more 'leeward' east line was generally less subject to burial than the west (Figs. 2 and 3).

\section{Microhabitat heterogeneity}

Ranking of the permanent samples by mean sand cover (Fig. 3), clearly indicated that sand effects were greatest in the pool quadrats of the west line. The most

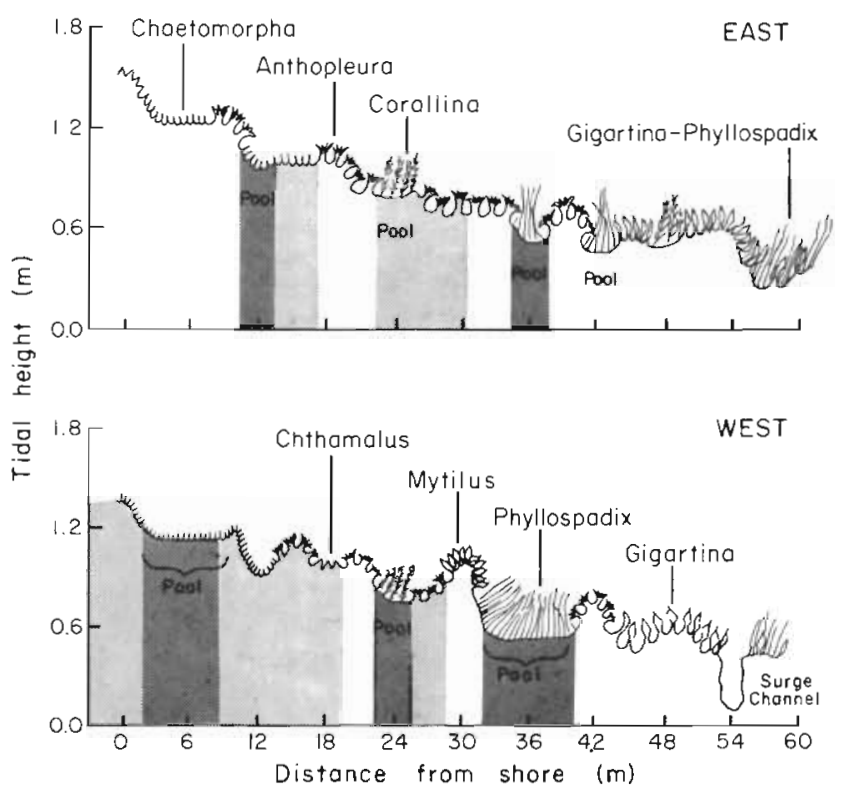

Fig. 3. Profiles of species assemblage zonal patterns and mean sand cover (Light shading $=<4 \%$, Medium $=$ $4-15 \%$, Dark $=15-27 \%$ ) as a function of tidal height and distance from shore. Assemblages, objectively determined and characterized from. Fig. 6, were used to label the quadrats along their respective transect lines

seaward samples were generally free of deposition and the remainder were influenced variously according to their local topographic features. Abruptly raised substrate pinnacles comprised 'islands' of reduced sand stress. In one case, a tidal height difference of $0.2 \mathrm{~m}$ between 2 adjacent samples resulted in a difference in mean sand cover of $37.9 \%$ ( $1.3 \%$ versus $39.2 \%)$. 


\section{Population distributions}

Species distribution and abundance patterns for September 1976 are presented (Figs, 3, 4 and 5) for baseline comparative purposes because this period characterized the habitat when sand was at its seasonal minimum. Between +0.6 and $+0.9 \mathrm{~m}$ [0 datum, mean lower low water (MLLW)], Chaetomorpha linum, Corallina vancouveriensis, Cladophora columbiana and Enteromorpha intestinalis were prominent (Fig. 4) along with the crustose forms of Lithophyllum proboscideum, Ralfsiaceae and blue-green algae. Chaetomorpha linum formed an extensive mat, with maximum cover of $34.7 \%$ within +1.2 to $+1.5 \mathrm{~m}$, and decreased to $1.3 \%$ between +0.6 and $+0.9 \mathrm{~m}$.

Below $+0.6 \mathrm{~m}$, Gigartina canaliculata became conspicuous along with Gastroclonium coulteri, Gelidium coulteri and Ulva lobata on emergent habitats, while Phyllospadix scouleri and its epiphyte Smithora naiadum occupied the wetter depressions. Gigartina canaliculata averaged $46.0 \%$ cover between +0.3 and $+0.6 \mathrm{~m}$ and $50.0 \%$ in the interval of MLLW to $+0.3 \mathrm{~m}$. Phyllospadix scouleri reached a maximum of $37.7 \%$ between MLLW and $+0.3 \mathrm{~m}$.

Prominent macroinvertebrates between +0.6 and $+1.5 \mathrm{~m}$ included Chthalamus fissus/dalli, Anthopleura elegantissima, Mytilus californianus and Tegula funebralis (Figs. 4 and 5). Chthamalus fissus/ dalli reached maximum abundance between +1.2 and $+1.5 \mathrm{~m}\left(26.1 \%\right.$ cover and 8,800 individuals $\left.\mathrm{m}^{-2}\right)$ and decreased rapidly lower on the shore. Anthopleura elegantissima was conspicuous over the entire range sampled and occupied a maximum of $20.6 \%$ cover $\left(508 \mathrm{~m}^{-2}\right)$ between +0.6 and $+0.9 \mathrm{~m}$. The transects sampled $M$. californianus only rarely, but an extensive population in one abruptly-raised quadrat yielded an average of $11.3 \%$ cover $\left(272 \mathrm{~m}^{-2}\right)$ between +0.9 and $+1.2 \mathrm{~m}$. Among the mobile macroinvertebrates in the same interval (Fig. 5), Collisella scabra attained the greatest density $\left(160 \mathrm{~m}^{-2}\right)$ and cover $(3.7 \%)$, although $T$. funebralis, Littorina scutulata, C. strigatella, and $C$. pelta were numerous.

Below +0.6 m, Anthopleura elegantissima remained prominent, while Tetraclita rubescens reached its relatively low maximum (cover $<1.0 \%, 286 \mathrm{~m}^{-2}$ ). Conspicuous mobile taxa included Mopalia muscosa with $4 \mathrm{~m}^{-2}$ in the interval of MLLW to $+0.3 \mathrm{~m}$ and Nuttallina fluxa/californica with $5 \mathrm{~m}^{-2}$ between +0.3 and $+0.7 \mathrm{~m}$. The sessile polychaetes Dodecaceria fewkesi and Phragmatopoma californica were also common at this level (Fig. 4).

\section{Seasonal overview}

The population data that form the basis for this section are detailed elsewhere (Littler and O'Brien, 1977; Littler, 1978; Littler and Martz, 1979) and are only summarized here. Reduced abundances for most of the conspicuous taxa were recorded following the December and February periods of maximum sand influence. Sand was not a factor during the assessments, so the reductions measured were real and not attributable to sampling problems. The macrophytes experiencing the greatest loss were typically opportunistic forms occupying the upper portions of the

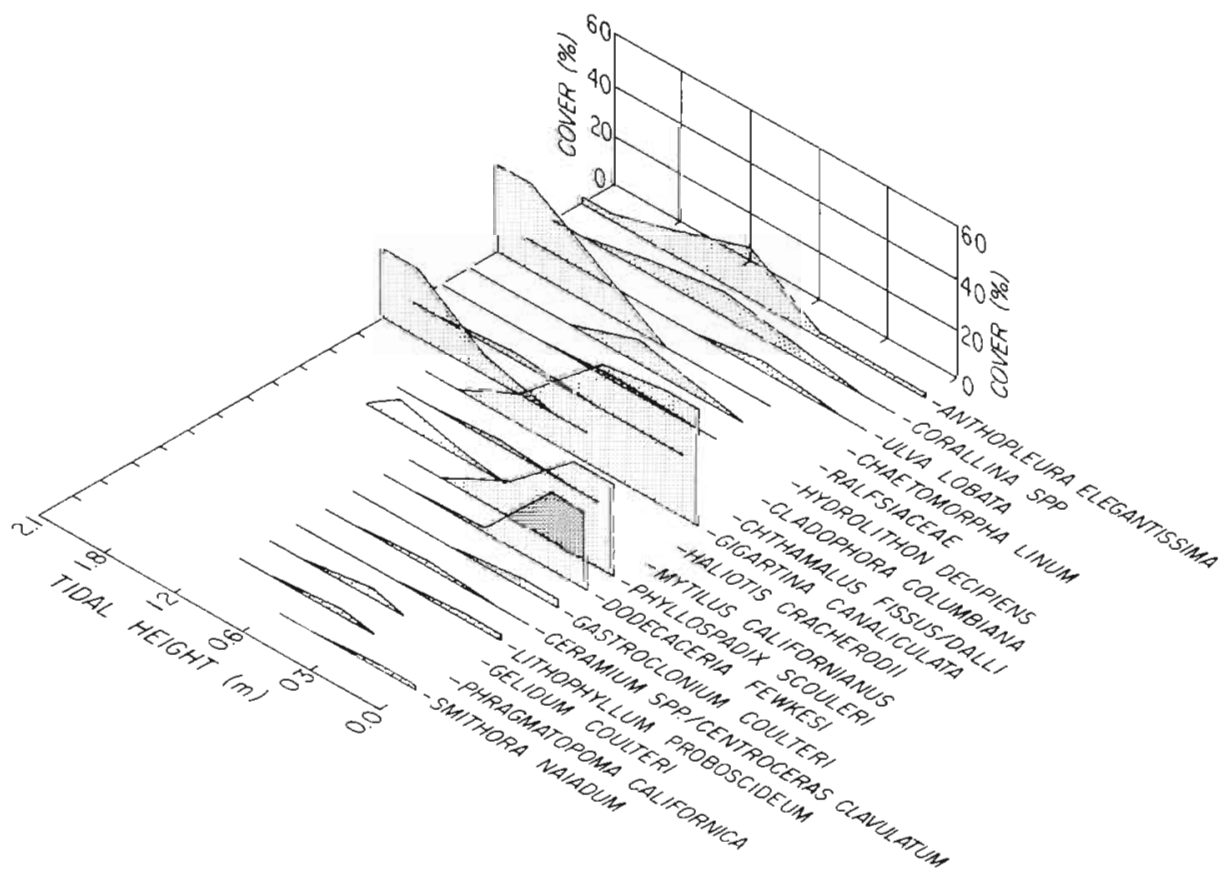

Fig. 4. Cover patterns as a function of tidal height for dominant macrophytes and sessile macroinvertebrates during September 1976 
Fig. 5. Density patterns as a function of tidal height for dominant mobile macroinvertebrates during September 1976

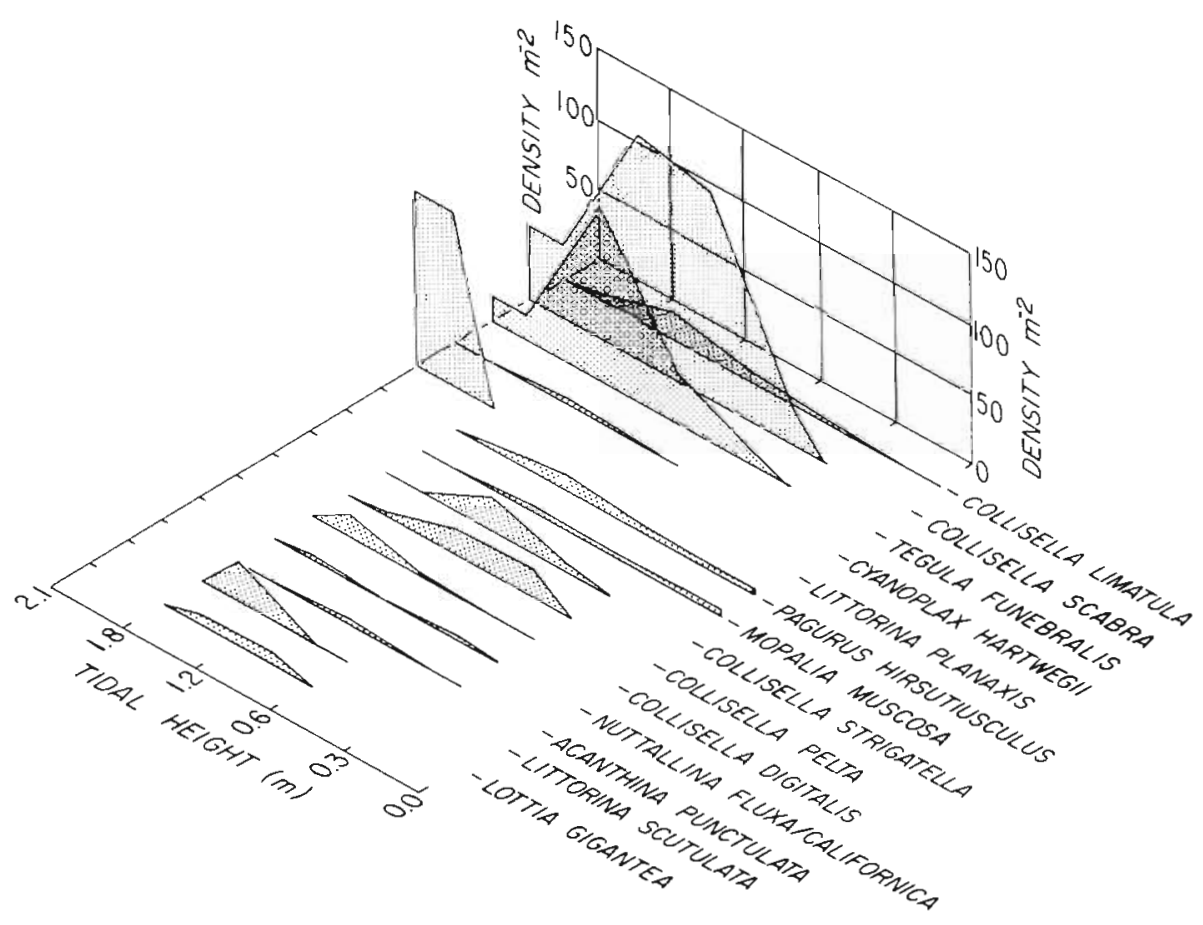

platform. For example, Chaetomorpha linum, Enteromorpha intestinalis, blue-green algae and Cladophora columbiana declined (significant at $\mathrm{P}$ $<.05$, Wilcoxon signed-rank analysis) by $3.4 \%, 0.4 \%$, $10.6 \%$ and $1.1 \%$ cover (all means are for the entire intertidal), respectively, from September to February.

Between September 1976 and February 1977, mean cover of the abundant high intertidal species Anthopleura elegantissima, Chthamalus fissus/dalli and Tegula funebralis decreased significantly $(\mathrm{P}<.05)$ by $2.8 \%, 3.4 \%$ and $0.6 \%$, respectively. Comparable reductions in density were noted for these taxa. Conversely, along the more seaward but raised portions of the transects during this season, Mytilus californianus, Lottia gigantea and Haliotis cracherodii remained fairly constant while Dodecaceria fewkesi showed a cover gain from $6.7 \%$ to $8.6 \%$ and Tetraclita rubescens increased from $0.1 \%$ to $0.5 \%\left(80 \mathrm{~m}^{-2}\right.$ to $150 \mathrm{~m}^{-2}$, $\mathrm{P}<.05)$. Recovery after winter sand burial was generally quite rapid and by each of the subsequent fall sampling periods, the predominant taxa had regained characteristic (e.g. Fig. 3) patterns of cover.

\section{Species assemblages}

Associations of quadrats and their prominent taxa were identified objectively by a correlation coefficient of similarity. The cover data for the taxa from all possible pairs of quadrats were compared by productmoment correlation and subjected to hierarchical clus- ter analysis (flexible-sorting) by the weighted pairgroup method (Sokal and Sneath, 1963). This produced a dendrogram (Fig. 6) of quadrat assemblages (indicated by distance along each line) that were then

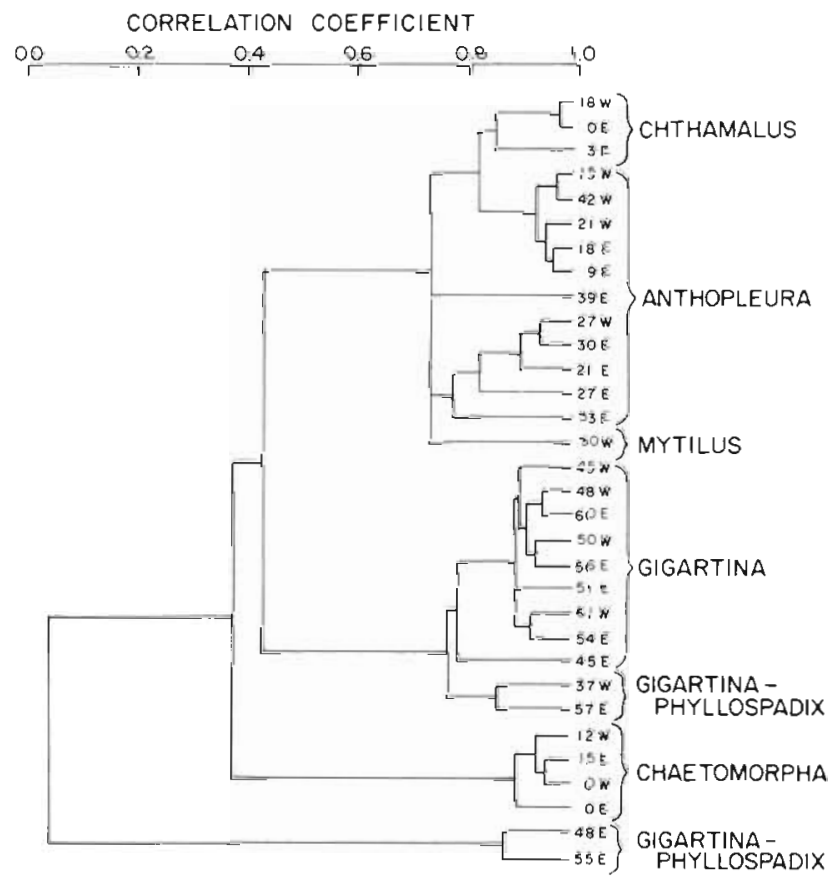

Fig. 6. Dendrogram display of differential clustering of all emergent quadrats (identified by their distance from shore), characterized by their cover dominants, based upon September 1976 cover data for all species within each quadrat on east and west transects 
characterized by their dominant species and used to label the quadrat positions along profile diagrams of each transect line (Fig. 3), Community types as categorized by this statistic (Fig. 3; based on the assemblages of Fig. 6) correlated strongly with the differential sand stress quantified in Fig. 3. In the tidepool habitats, species assemblages of the west line (Fig. 3) were associated with a mean sand cover of $24.5 \%$ or more and experienced maximum burial of at least $88.0 \%$. The east line pools were impacted slightly less but were composed of similar associations. Between +0.9 and $+1.2 \mathrm{~m}$, the tidepools approached a monoculture of the opportunist Chaetomorpha linum. Between +0.6 and $+0.9 \mathrm{~m}$ in pools, Corallina vancouveriensis expanded its standing stocks along with blue-green algae and Phyllospadix scouleri. These tidepools contained relatively few invertebrates and were biotically intermediate between the higher Chaetomorpha-dominated pools and the lower Phyllospadix-dominated ones. The tidepool samples from +0.3 and $+0.6 \mathrm{~m}$ (Fig. 3) contained an overstory of Phyllospadix scouleri that approached $100 \%$ cover. Sand was present throughout all seasons in these low pools.

In addition to the 2 tidepool assemblages, there were 5 major associations (Fig. 6) characteristic of the emergent rock samples. Average sand cover was $8.8 \%$ for these raised quadrats as compared to $37.6 \%$ for pools. Above $+0.9 \mathrm{~m}$, the following 2 groups were evident: (1) Chaetomorpha-Group and (2) Chthamalus-Group. The Chaetomorpha assemblage (also prevalent in upper pools) consisted primarily of Chaetomorpha linum, with Corallina spp., Enteromorpha intestinalis, Ulva lobata and Cladophora columbiana occasionally present. The invertebrates Tegula funebralis and Anthopleura elegantissima were also commonly observed in these samples. The Chthalamus-Group was composed of abundant C. fissus/dalli and Littorina spp. along with $T$. funebralis and blue-green algae.

Between +0.3 and +0.9 m (Figs. 3 and 6), 3 major groups were distinguished: (1) Anthopleura-Group, (2) Gigartina-Group and (3) Gigartina-PhyllospadixGroup. The Anthopleura association was distinguished by abundant clones of $A$. elegantissima along with Tegula funebralis, Collisella scabra, Corallina spp. and Lithophyllum proboscideum. The GigartinaGroup exhibited high cover of Gigartina canaliculata and Corallina spp. that grew upon a secondary substrate of Phragmatopoma californica. The GigartinaPhyllospadix-Group was similar to the GigartinaGroup with the exception of increased $P$. scouleri cover and the replacement of Phragmatopoma californica by Dodecaceria fewkesi.

A unique assemblage on the rock pinnacle habitat (Figs. 3 and 6, W30) was characterized as the Mytilus-
Group and was composed of at least $50.0 \%$ cover of $M$. californianus. Abundant species within this assemblage of long-lived animals were $M$. californianus, Collisella scabra, Haliotis cracherodii and Lottia gigantea. Other species of the genus Collisella also were common, whereas frondose macrophytes were poorly represented; the encrusting forms Peyssonnelia sp. and Ralfsiaceae were present with cover values usually below $20 \%$. This pinnacle community type was abundantly represented just to the northeast of our transect lines where the influence of sand was minimal. Throughout all of our site visits, these raised $M$. californianus beds remained constant and free of sand. Aside from the period of stressful deposition of sand during the winter months, all of the above species associations generally were present throughout the 3 yr study.

\section{Adaptations}

One long-lived macroinvertebrate that grazed the Chaetomorpha-Group was Tegula funebralis (Taylor and Littler, 1982). This gastropod consistently escaped sand burial by moving to areas of low sand stress (Fig. 7). T. funebralis densities rose dramatically during the winter months in 2 quadrats (W21, E18) that were never completely inundated (always below $10 \%$ sand cover). This density increase in benign habitats and simultaneous decrease among adjacent sandexposed samples was repeated annually and documents the migration of $T$. funebralis in response to

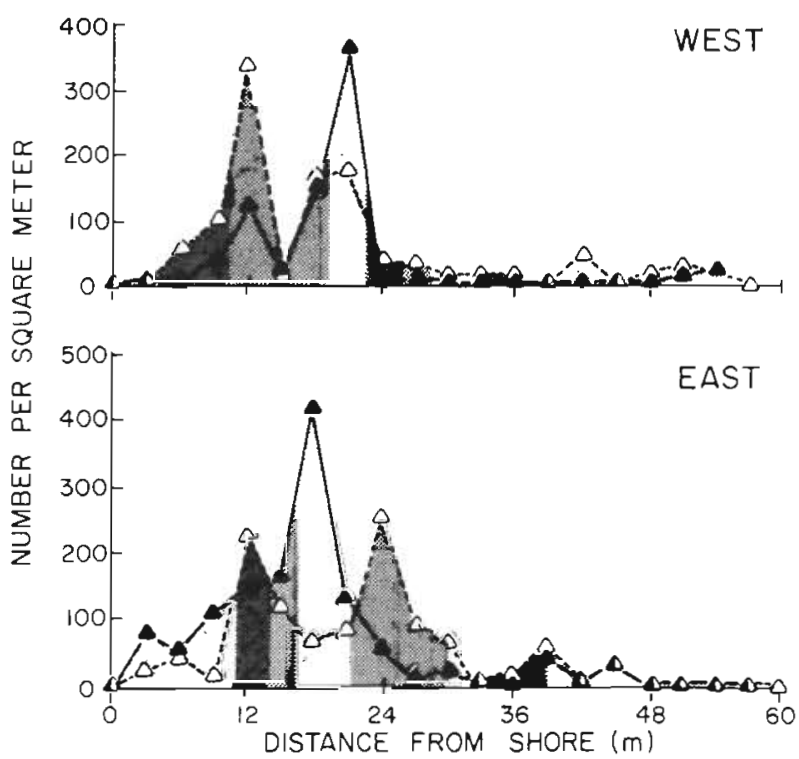

Fig. 7. Tegula funebralis. Characteristic migration as a function of winter sand inundation for both west and east transect lines Light triangles $=$ September 1976 , dark triangles $=$ December 1976. Shading indicates mean sand cover as in Fig. 3. 
increasing sand cover. A general movement away from the west line is also indicated by a drop in mean density from 56 to $39 \mathrm{~m}^{-2}$ between September and December while density on the east line increased from 46 to $55 \mathrm{~m}^{-2}$. $T$. funebralis was observed to expand back into formerly inundated areas as the sand retreated.

Simultaneously, densities of adult Collisella scabra, another common mobile herbivore, increased slightly in the same benign samples in which Tegula funebralis became concentrated, although its emigration was not as extensive (possibly because of its homing tendency) as that of $T$. funebralis.

The chiton Mopalia muscosa remained in place through several weeks of sand burial (up to $10 \mathrm{~cm}$ deep) at Dutch Harbor as well as elsewhere (e.g nearby rocky platforms, own obs.) with no apparent detrimental effects. This was also the case for shallower burials of clones of Anthopleura elegantissima, which routinely extended their columns to maintain their tentacles and oral discs at the surface.

The surf grass Phyllospadix torreyi was always associated with sand that it trapped by means of its rhizomatous root system, while maintaining its long thin leaves well above the level of the substrate.

\section{DISCUSSION}

In addition to the environmental stresses imposed by the normal tidal cycles and seasonal weather conditions (e.g. desiccation, insolation, heating, rainfall) most of the intertidal biota at the San Nicolas Island study site appeared to be severely affected by stresses brought about through recurrent sand deposition. Sand has been reported (Cimberg et al., 1973) to scour physically the underlying substrate allowing for recolonization when the substrate re-emerges. However, Taylor and Littler (1982) distinguished different effects due to sand-induced stress (smothering) and disturbance (scour), with a greater effect due to the former at the same site studied here. The majority of quadrats throughout the tidal range from +0.3 to $+1.2 \mathrm{~m}$ were routinely inundated by sand during the winter months (Fig. 2). Sand deposition was greatest on the west transect and slightly less on the east line (Figs. 2 and 3); tidepools were consistently inundated first, followed by the lower exposed areas; the upraised pinnacle portions of the bench remained unburied. A cycle of deposition and removal occurred annually with winter maxima (Fig. 2) and the species abundance patterns were related to the relative degree of sand stress on different portions of the study site (Fig. 3).

A three-strategy model of adaptive specialization has been proposed (Grime, 1977) for terrestrial plants and this forms a useful paradigm within which to frame several of the phenomena we observed for marine plants and sessile invertebrates near Dutch Harbor. According to this model (as applied by Vermeij, 1978), species can be categorized as: (1) Opportunists; these show high reproductive output, a short life history, high dispersibility, reduced long-term competitive abilities and occupy ephemeral or disturbed habitats. (2) Stress-tolerant forms; these can tolerate chronic physiological stress, exhibit low rates of recolonization, tend to be long-lived with slow growth rates and, consequently, are generally poor competitors. (3) Biotically-competent forms; these generally live in physiologically-favorable environments, have long life spans, are good competitors and have evolved mechanisms to reduce predation. In the rocky intertidal zone, Vermeij identifies stress-tolerant forms as characteristic of the upper intertidal habitat, whereas biotically-competent taxa are prevalent in the low intertidal zone. Opportunistic forms would appear ephemerally on disturbed or newly available substrates.

An apparent subclimax association of delicate highproducing macrophytes (Littler, $1980 \mathrm{~b}$; Littler and Littler, $1980 \mathrm{~b}$ ) and highly-reproductive macroinvertebrates that correspond to the ruderal (opportunistic) strategists (sensu Grime, 1977) dominated the lowlying areas routinely buried by sand and exhibited a zonational pattern reflecting both tidal height and degree of sand coverage (Fig. 3). A number of characteristics can be related (Odum, 1969) to those species subjected to recurrent mortalities due to sand stress, including: (1) high productivity, (2) low biomass, (3) opportunistic life histories and (4) emphasis on the herbivore trophic level. For example, high productivity has been reported for Ulva lobata, Enteromorpha intestinalis, Cladophora columbiana and Chaetomorpha linum (Littler, 1980 b; Littler and Arnold, 1982), which are all of low biomass per unit area (Appendix A, in Littler, 1977). Opportunistic reproductive strategies have been indicated for Enteromorpha sp. (Fahey, 1953) and Ulva sp. (Littler and Murray, 1974). These 2 macrophytes, well-documented to be rapid colonizers (Crapp, 1971; Littler and Murray, 1975; Sousa, 1979a; Littler, $1980 \mathrm{~b}$ ), also proliferated rapidly at a study site near Santa Barbara, California (O'Brien and Littler, 1977) where winter sand movements had created patches of bare substrate. Removal studies carried out at Dutch Harbor (Murray and Littler, 1979; Taylor and Littler, 1982) indicated that $C$. linum has rapid recovery capabilities following mechanical disturbance. In this regard, newly cleared free space, next to the same transects studied here (Murray and Littler, 1979), was first colonized by these same species of opportunistic algae, such as Chaetomorpha linum, Cladophora col- 
umbiana, Enteromorpha intestinalis and Ralfsiaceae (cf. Northcraft, 1948; Dayton, 1975; Littler and Murray, 1978; Dethier, 1981), and by the barnacles Chthamalus fissus/dalli along with the tube-worm Phragmatopoma californica. All of these invertebrates have high and nearly continuous reproductive output (Hines, 1978; Taylor and Littler, 1982). The prominent algae within the subclimax Chaetomorpha-Group and its associates have a filamentous morphology prevalent among sand-dwelling forms (Mathieson, 1965, 1967; Daly and Mathieson, 1977) recorded at other localities.

Prominent among the subclimax fauna are longlived species capable of adjusting to stresses imposed by sand. Tegula funebralis is highly mobile and migrated away from the winter sand flow to refuge habitats (Fig. 7). The slower moving Mopalia muscosa did not migrate but appeared to withstand burial over long periods, which would place it among the stresstolerant category (sensu Grime, 1977). Anthopleura elegantissima dominates the upper intertidal macroinvertebrate cover at Dutch Harbor and also corresponds to the stress-tolerant strategists of Grime (1977) because it is adapted reproductively (Hand, 1955; Francis, 1976), behaviorally (Hart and Crowe, 1977), and physiologically (Shick et al., 1979) to the stresses caused by sand deposition and aerial exposure. Since $A$. elegantissima reproduces asexually by binary longitudinal fission, the relatively large 'recruits' have the advantage of reduced surface/volume ratios and, presumably, increased desiccation resistance. Resistance to desiccation also is provided by the attachment of gravel and shell fragments to the outer wall verrucae (Hart and Crowe, 1977), which produces a larger boundary layer of high humidity. Shick et al. (1979) indicated a high permeability of the body wall to oxygen, reduction of oxygen demand and relative lack of oxygen debt during aerial exposure as adaptive characteristics in this species. At Coal Oil Point, California, $A$. elegantissima similarly was observed to resist shallow sand burial (O'Brien and Littler, 1977), by extending its columns so that the oral disc and tentacles projected above the surface. Metabolism of body tissue is probably the primary mechanism (Sebens, 1980) for survival during prolonged ( $>3 \mathrm{mo}$.) deeper burial.

In areas where rock contours provided a refuge from sand deposition, quite different biological communities prevailed, corresponding somewhat with the biotically-competent strategists of Vermeij (1978; cf. Grime, 1977). Refuge habitats (e.g. W30 in Fig. 3) were available when surface contours provided virtual 'islands' of rock substrate raised above the sand deposits. If the raised area was sharply elevated above the surrounding rock, an additional refuge with respect to sand flow was provided along its 'lee' side.
Assemblages of long-lived species, such as Mytilus californianus, Lottia gigantia and Haliotis cracherodii, were isolated upon these habitats and also were extensive along the eastern edge of the bench where sand did not penetrate. The Mytilus association was characterized primarily by biotically-competent strategists having relatively large biomass, slow growth, biological interactions and other features typical of communities in late stages of development (Connell, 1975; Littler and Littler, 1981). For example, M. californianus has long been known (Paine, 1966; Dayton, 1971) to dominate competitively wave-exposed intertidal shores. Also, interference competition and predator avoidance behavior has been documented for Lottia gigantea (Stimson, 1970) and Haliotis cracherodii (Feder, 1963), respectively. The recovery period following complete harvesting of most of the invertebrates found in the mature Mytilus-Group of the raised pinnacles was the most prolonged of any assemblage and only reached initial stages of recolonization during the 3 yr of this and other (Murray and Littler, 1979; Taylor and Littler, 1982) studies.

Interestingly, Connell (1972, p. 172) states that 'at the present time there is apparently no evidence that any intertidal species is prevented from extending to a lower level by intolerance to the physical conditions there'. The raised pinnacle communities are of interest in that their lower limits clearly appear to be determined by the physical smothering action of sand burial, in accordance with the interpretation of Daly and Mathieson (1977), rather than by the kinds of biological factors so well documented in the literature (see Paine, 1966; Connell, 1972).

Sand inundation resulted in subclimax and mature intertidal communities being intermingled in a mosaic-like pattern (Fig. 3) on San Nicolas Island and this augmented the within-habitat diversity (mean Shannon-Weaver $H^{\prime}=2.75$ ). Levin and Paine (1974) predicted and others (Sousa, 1979a, b; Littler and Littler, 1981) found that disturbances such as sand and rock movement, when localized, may increase diversity as a result of mixed patches containing populations undergoing different stages of succession. This agrees with the subtidal data of Foster (1975), whereby sand scour raised overall kelp bed diversity.

The dominant in lower sand-inundated pools, Phyllospadix scouleri, is a long-lived perennial plant (biotically-competent strategist sensu Vermeij, 1978) that tolerates sand because of its large size and its rhizomatous root system which binds sediment. Similarly, O'Brien and Littler (1977) observed that $P$. torreyi increased in cover relative to other organisms when sand cover was highest and appeared to be favored by the presence of sand. Organisms surviving and dominating areas of extensive sand innundation (e.g. 
Sphacelaria radicans, Ahnfeltia plicata) have been characterized (Daly and Mathieson, 1977) as psammophytic or 'sand-loving'. Implicit in this viewpoint is that growth rates and/or reproduction (i.e. fitness) are enhanced by the presence of sand which gives them competitive superiority over other space occupiers; e.g. $P$, scouleri which dominated sand-inundated lower tidepools. However, alternative interpretations come to mind and there appear to be several possible functional groups of organisms associated with sandstressed intertidal systems. In addition to the potentially psammobiotic or 'sand-enhanced' group of organisms, there is the opportunistic group le.g. Chaetomorpha, Ulva, Enteromorpha, barnacles, Phragmatopoma) whose members rapidly repopulate space following mortalities due to burial. Associated with these are the 'migratory strategists' (e.g. Tegula funebralis, Fig. 7) that move in and out of the system as stress gradients change. Fourthly, there is a stresstolerant group of organisms, such as Anthopleura elegantissima (also Mopalia muscosa and possibly some coralline algae), which because of their physiological, behavioral and morphological adaptations are able to survive burial where potentially superior competitors (e.g. mussels, large differentiated algae; Chapman, 1943; Markham, 1973; Daly and Mathieson, 1977) cannot survive or reproduce. With the possible exception of $P$. scouleri, there is little evidence that the growth rates and reproductive output of any 'psammophyte' are enhanced by the presence of sand to the point that competitive superiority is conferred over other species. Quite the contrary, many may actually be inhibited by sand but relegated to sandy habitats (refugia) by biological constraints such as predation of competition. The morphological and reproductive adaptations of so-called sand-loving algae such as: (1) tough thalli, (2) regeneration of upright portions from remnant bases, and (3) incomplete alternation of sexual and asexual generations cited by Daly and Mathieson (1977), are all criteria that fit the fourth functional group above. Interestingly, when not stressed by sand or aerial exposure, the anemone $A$. elegantissima abandons its clonal habit and becomes quite robust and solitary (Francis, 1976; Sebens, 1980). The research reported here suggests that sand-stressed habitats, with relatively few exceptions, serve as important refuges for two functional groups of fugitive species; i.e. stress-tolerant strategists and opportunistic strategists.

Acknowledgements. We gratefully acknowledge the Bureau of Land Management, United States Department of the Interior, for its support through their Outer Continental Shelf Research Program (Contract No. AA550-CT6-40). We are deeply appreciative of the consistently thorough field work performed under less than optimal conditions by Jerry Aba- jian, Joyce Cook, Maurice Hill, Donn Marrin, Shirli Ouimette, Mark Schildhauer, Peggy Trabue, Lynnette Vesco and Janet Wheeler We also are appreciative of the photographic assistance provided by Chuck Currie and Ron Mizusawa. We thank our colleagues Keith Arnold, Roger Seapy and Phillip Taylor for their helpful suggestions on early drafts of this manuscript.

\section{LITERATURE CITED}

Chapman, V. J. (1943). Zonation of marine algae on the seashore. Proc. Linn. Soc., Lond. 154: 239-253

Cimberg, R. L., Mann, S., Straughan, D. (1973). A reinvestigation of southern California rocky intertidal beaches three and one-half years after the 1969 Santa Barbara oil spill: a preliminary report. In: Proceedings of joint conference on prevention and control of oil spills. American Petroleum Institute, Washington, D. C., p. 697-702

Connell, J. B. (1961). The influence of interspecific competition and other factors on the distribution of the barnacle Chthamalus stellatus. Ecology 42: 710-723

Connell, J. H. (1972). Community interactions on marine rocky intertidal shores. Ann. Rev. Ecol. Syst. 3: 169-192

Connell, J. H. (1975). Some mechanisms producing structure in natural communities: a model and evidence from field experiments. In: Cody, M. L., Diamond, J. M. (eds.) Ecology and evolution of communities. Belknap Harvard Press, Cambridge, Massachusetts, p. 460-490

Crapp, G. B. (1971). The ecological effects of standard oil. In The ecological effects of oil pollution on littoral communities. Applied Science Publications, Essex, p. 181-207

Daly, M. A., Mathieson, A. C. (1977). The effects of sand movement on intertidal seaweeds and selected invertebrates at Bound Rock, New Hampshire, USA. Mar Biol. 43: $45-55$

Dawes, C. J., Moon, R. E., Davis, M. A. (1978). The photosynthetic and respiratory rates and tolerances of benthic algae from a mangrove and salt marsh estuary: a comparative study. Estuar, coast. mar. Sci. 6: 175-185

Dayton, P. K. (1971). Competition, disturbance, and community organization: the provision and subsequent utilization of space in a rocky intertidal community. Ecol. Monogr. 41: 351-389

Dayton, P. K. (1975). Experimental evaluation of ecological dominance in a rocky intertidal algal community. Ecol. Monogr. 45: 137-159

Dethier, M. N. (1981). Heteromorphic algal life histories: the seasonal pattern and response to herbivory of the brown crust, Ralfsia californica. Oecologia (Berl.) 49: 333--339

Devinny, J. S., Volse, L. A. (1978). Effects of sediments on the development of Macrocystis pyrifera gametophytes. Mar. Biol. 48: 343-348

Ebling, F. J., Sleigh, M. A., Sloane, J. F., Kitching, J. A. (1960) The ecology of Lough Ine, VII. Distribution of some common plants and animals of the littoral and shallow sublit toral regions. J. Ecol. 48: 29-53

Fahey, E. M. (1953). The repopulation of intertidal transects. Rhodora 55: 102-108

Feder, H. M. (1963). Gastropod defensive responses and their effectiveness in reducing predation by starfishes. Ecology 44: 505-512

Foster, M. S. (1975). Algal succession in a Macrocystis pyrifera forest. Mar. Biol. 32: 313-329

Francis, L. (1976). Social organization within clones of the sea anemone Anthopleura elegantissima. Biol. Bull. mar. biol. Lab. Woods Hole 150: 361-376

Grime, J. P. (1977). Evidence for the existence of three pri- 
mary strategies in plants and its relevance to ecological and evolutionary theory. A.m. Nat. 111: 1169-1194

Hand, C. (1955). The sea anemones of central California, Part II, The Endomycirian and Mesomyarian anemones. Wasmann J. Biol. 13: 37-99

Hart, C. E., Crowe, J, H. (1977). The effect of attached gravel on survival of intertidal anemones. Trans. Am. microsc. Soc. 96: $28-41$

Hedgpeth, J. W (1957). Sandy beaches. In: Hedgpeth, J. W (ed.) Treatise on marine ecology and paleoecology, Vol. I. Ecology. The Geological Society of America, Boulder, Colorado (Mem. Geol. Soc. Am. 67: 587-608)

Hines, A. H. (1978). Reproduction in three species of intertidal barnacles from central California. Biol. Bull. mar. biol. Lab., Woods Hole 154: 262-281

Jones, W E., Demetropoulos, A. (1968). Exposure to wave action: measurements of an important ecological parameter on rocky shores on Anglesey. J. exp. mar. Biol. Ecol. 2: $46-63$

Kitching, J. A. (1941). Studies in sublittoral ecology. III. Laminaria forest on the west coast of Scotland: a study of zonation in relation to wave action and illumination. Biol. Bull. mar biol. Lab., Woods Hole 80: 324-337

Kitching, J. A., Macan, T. T., Gilson, H. C. (1934). Studies in sublittoral ecology. I. A submarine gully in Wembury Bay, South Devon. J. mar. biol. Ass. U. K. 19:677-705

Levin, S. A., Paine, R. T. (1974). Disturbance, patch formation, and community structure. Proc. natn. Acad. Sci. USA 71 : $2744-2747$

Lewis, J. R. (1964). The ecology of rocky shores. English Universities Press Ltd, London

Lewis, J. R. (1968). Water movements and their role in rocky shore ecology. Sarsia 34: 13-36

Lilly, S. J., Sloane, J. F., Bassingdale, R., Ebling, F. J., Kitching, J. A. (1953). The ecology of the Lough Ine rapids with special reference to water currents. J. Anim. Ecol. 22: $87-122$

Littler, M. M. (1971). Standing stock measurements of crustose coralline algae (Rhodophyta) and other saxicolous organisms. J. exp. mar. Biol. Ecol. 6: 91-99

Littler, M. M. (1977). Spatial and temporal variations in the distribution and abundance of rocky intertidal and tidepool biotas in the Southern California Bight. Bureau of Land Management, U.S. Department of the Interior, Washington, D. C

Littler, M. M. (1978). Variations in the rocky intertidal biota near Dutch Harbor, San Nicolas Island, California. In: Littler, M. M. (ed.) Intertidal study of the Southern California Bight, 1976/77, Vol. III. Bureau of Land Management, U.S. Department of the Interior, Washington, D. C., p. III-1.1.8-1 to III-1.1.8-79

Littler, M. M. (1980a). Overview of the rocky intertidal systems of Southern California. In: Power, D. M. (ed.) The California islands: proceedings of a multidisciplinary symposium. Santa Barbara Museum of Natural History, Santa Barbara, California, p. 265-306

Littler, M. M. (1980 b). Morphological form and photosynthetic performances of marine macroalgae: tests of a functional/form hypothesis. Botanica mar. 22: 161-165

Littler, M. M., Arnold, K. E. (1980). Sources of variability in macroalgal primary productivity: sampling and interpretative problems. Aquat. Bot. 8: 141-156

Littler, M. M., Arnold, K. E. (1982). The primary productivity of marine macroalgal functional-form groups from southwestern North America. J. Phycol. 18: 307-311

Littler, M. M., Littler D. S. (1980a). Mainland rocky intertidal aerial survey from Point Arguello to Point Loma, Califor- nia. Bureau of Land Management, U. S. Department of the Interior, Washington, D. C

Littler, M. M., Littler, D. S. (1980 b). The evolution of thallus form and survival strategies in benthic marine macroalgae: field and laboratory tests of a functional form model. Am. Nat. 116: 25-44

Littler, M. M., Littler, D. S. (1981). Intertidal macrophyte communities from Pacific Baja California and the upper Gulf of California: relatively constant vs. environmentally fluctuating systems. Mar. Ecol. Prog. Ser. 4: 145-158

Littler, M. M., Martz, D. R. (1979). Assessments of the distribution, abundance and community structure of rocky intertidal organisms at Dutch Harbor, San Nicolas Island, Califormia. In: Littler, M. M. (ed.) Intertidal study of the Southern California Bight, $1977 / 78$ (third year). Vol. II, Report 1. Bureau of Land Management, U. S. Department of the Interior, Washington, D. C., p. II-1.19-1 to II-1.19-74

Littler, M. M., Murray, S. N. (1974). The primary productivity of marine macrophytes from a rocky intertidal community Mar. Biol. 27: 131-135

Littler, M. M., Murray, S. N. (1975). Impact of sewage on the distribution, abundance and community structure of rocky intertidal macro-organisms. Mar. Biol. 30: 277-291

Littler, M. M., Murray, S. N. (1978). Influence of domestic wastes on energetic pathways in rocky intertidal communities. J. appl. Ecol. 15: 583-595

Littler, M. M., O'Brien, P. Y. (1977). Biological features of rocky intertidal communities near Dutch Harbor, San Nicolas Island, California. In: Littler, M. M. (ed.) Spatial and temporal variations in the distribution and abundance of rocky intertidal and tidepool biotas in the Southern California. Bight Bureau of Land Management, U.S. Department of the Interior, Washington, D. C., p. 605-686

Markham, J. W. (1973). Observations on the ecology of Laminaria sinclairii on three northern Oregon beaches. J. Phycol. 9: 336-341

Mathieson, A. C. (1965). Contributions to the life history and ecology of the marine brown alga, Phaeostrophion irregu lare S. et G. Ph. D. Dissertation, University of British Columbia, Vancouver

Mathieson, A. C. (1967). Morphology and life history of Phaeostrophion irregulare S. et G. Nova Hedwigia 13: 293-318

Mathieson, A. C., Burns, R. L. (1971). Ecological studies of economic red algae. I. Photosynthesis and respiration of Chondrus crispus Stackhouse and Gigartina stellata (Stackhouse) Batters. J. exp. mar. Biol. Ecol. 7: 197-206

Mathieson, A. C., Fralick, R. A. (1972). Investigations of New England marine algae $V$. The algal vegetation of the Hampton-Seabrook Estuary and the open coast near Hampton, New Hampshire. Rhodora 74: 406-435

Menge, B. A. (1972). Competition for food between two intertidal starfish species and its effect on body size and feeding. Ecology 53: 635-644

Murray, S. N., Littler, M. M. (1979). Experimental studies of the recovery of populations of rocky-intertidal macroorganisms following mechanical disturbance, Southern California Baseline Study, Year Three, Vol. III, 2.0. Bureau of Land Management, U.S. Department of the Interior, Washington, D. C.

Neushul, M., Foster, M. S., Coon, C. A., Woessner, J. W. Harger, B. W W. (1976). An in situ study of recruitment, growth and survival of subtidal marine algae: techniques and preliminary results. J. Phycol. 12: 397-408

Northcraft, R. D. (1948). Marine algal colonization on the Monterey Peninsula, California. Am. J. Bot. 35: 396-404 
Norton, T A., Hiscock, K., Kitching, J, A. (1977). The ecology of Lough Ine, XX. The Laminaria forest at Carrigathorna. J. Ecol. 65: 919-941

O'Brien, P. Y., Littler, M. M. (1977). Biological features of rocky intertidal communities at Coal Oil Point, Santa Barbara County, California. In: Littler, M. M. (ed.) Spatial and temporal variations in the distribution and abundance of rocky intertidal and tidepool biotas in the Southern California Bight. Bureau of Land Management, U.S. Department of the Interior, Washington, D. C., p. 317-405

Odum, E. P. (1969). The strategy of ecosystem development. Science, N. Y. 164: 262-270

Paine, R. T (1966). Food web complexity and species diversity. Am. Nat. 100: 65-75.

Schonbeck, M., Norton, T. A. (1978). Factors controlling the upper limits of fucoid algae on the shore. J. exp. mar. Biol. Ecol. 31: 303-313

Seapy, R. R., Littler, M. M. (1978). The distribution, abundance, community structure, and primary productivity of macroorganisms from two central California rocky intertidal habitats. Pacif. Sci. 32: 293-314

Sebens, K. P. (1980). The regulation of asexual reproduction and indeterminate body size in the sea anemone Anthopleura elegantissima (Brandt). Biol. Bull. mar. biol. Lab., Woods Hole 158: 370-382
Shephard, F. P. (1973). Submarine geology, 3rd. ed. Harper and Row, New York

Shick, J. M., Brown, W. I., Dolliver, E. G., Kayar, S. R. (1979). Oxygen uptake in sea anemones: effects of expansion. contraction, and exposure to air and the limitations of diffusion. Physiol. Zool. 52: 50-62

Sokal, R. R., Sneath, P. H. A. (1963). Principles of numerical taxonomy. $W \mathrm{H}$. Freeman and Co., San Francisco, California

Sousa, W. P. (1979a). Experimental investigations of disturbance and ecological succession in a rocky intertidal algal community. Ecol. Monogr. 49: 227-254

Sousa, W. P. (1979b). Disturbance in marine intertidal boulder fields: the nonequilibrium maintenance of species diversity. Ecology 60: 1225-1239

Stimson, J. S. (1970). Territorial behavior in the owl limpet Lottia gigantea. Ecology 51: 113-118

Taylor, P. R., Littler, M. M. (1982). The roles of compensatory mortality, physical disturbance, and retention substrate in the development and organization of a sand-influenced, rocky-intertidal community. Ecology 63: 135-146

Vadas, R. L. (1977). Preferential feeding: an optimization strategy in sea urchins. Ecol. Monogr. 47: 337-371

Vermeij, G. J. (1978). Biogeography and adaptation patterns of marine life. Harvard University Press, Cambridge

This paper was presented by Professor J. S. Pearse; it was accepted for printing on November 26, 1982 